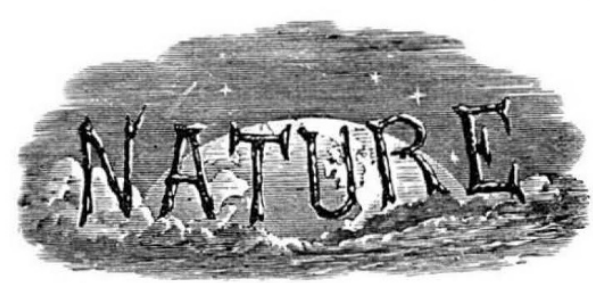

SATURDAY, MAY 2I, 1932

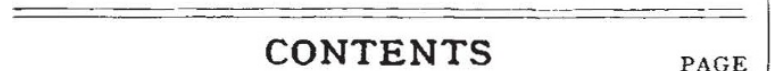

Co-ordination of Government Grants for Research and Development.

The Mind Judicial. By Prof. Henry E. Armstrong, F.R.S.

Teaching of Mathematics. By Dr. P. B. Ballard

Systematic Zoology

Short Reviews

The Uncertainty Principle in Modern Physics. By Dr. H. T. Flint

The Great Barrier and the Formation of Coral Reefs.

By Prof. J. Stanley Gardiner, F.R.S

Obituary :

Prof. Wilhelm Ostwald. By Prof. Alex. Findlay

Dr. H. T. Ferrar. By Dr. Bernard Smith .

News and Views

Letters to the Editor:

Suggested Wireless Observations during the Solar Eclipse of August 31, 1932-Prof. E. V. Appleton, F.R.S., and Prof. S. Chapman, F.R.S

Photodichroism Produced by $a$-Particles. $-D r$. A. M. Taylor .

Stark Effect for Argon.-Dr. Nils Ryde

The Auroral Spectrum in the Infra-Red.--Dr. W. Jevons

Sound-change and Indeterminism.-Alan S. C. Ross

Crystal Lattice Distortion in Stretched Wire.W. A. Wood

The True Weight of Benzopurpurin 4B, and the Electrical Conductivity of its Aqueous Solutions.-S. M. Neale and J. Hanson.

Formation of Periodic Precipitates in the Absence of a Foreign Gel.-Prof. N. R. Dhar and R. N. Mittra

Winter in the Ionosphere.-R. A. Watson Watt

The Tectonics of the Albertine Rift.-E. J. Wayland

An Inherited Abnormality in Rhode Island Red Poultry.-Ruth C. Bamber (Mrs. Bisbee)

Research Items

Astronomical Topics

Scientific Management in Industry .

The Idu (Japan) Earthquake of I930

The British Iron and Steel Industry.

The Plant in Relation to Water

University and Educational Intelligence

Calendar of Geographical Exploration

Societies and Academies.

Forthcoming Events

Official Publications Received .

Editorial and Publishing Offices :

MACMILLAN \& CO., LTD.

ST. MARTIN'S STREET, LONDON, W.C. 2

Editorial communications should be addressed to the Editor Advertisements and business letters to the Publishers

Telephone Number: WHITEHALL 8831

Telegraphic Address: PHUSIS, LESQUARE, LONDON

No. 3264, VoL. 129]

\section{Co-ordination of Government Grants for Research and Development}

TTHE War brought about a recognition of the value and application of research in solving the many problems which arose during the continuance of the struggle. As is well known, Germany, both in government and commercial circles, had recognised the value of research work before the dawn of the present century. The years following the Armistice have furnished evidence that if the British Empire is to keep pace with its competitors it must make the fullest use of the scientific worker in dealing with the complicated questions of administration and development which confront it. It is of good augury that this fact is now appreciated both by the Government of Great Britain and those responsible for the Empire overseas, the subject having been discussed at the Conferences of Prime Ministers which have been held in London.

Omitting for the moment the wider issues of this matter, a brief survey may be made of the developments which have taken place in Great Britain. As a forerunner of newer bodies at present in existence here, the Development Fund was inaugurated in 1910. The objects of this fund were to provide assistance, after due inquiry, to agriculture, fisheries, forestry, and so forth, in the form of grants for education, research, and other development work. After the War other interests arose, some of them conflicting, though this was not appreciated at the time. Bodies such as the Empire Marketing Board, the Colonial Development Fund, and the Colonial and Middle Eastern Services were formed, whilst increased grants for various new purposes were made to the Ministry of Agriculture and to the University Grants Committee.

These newer bodies and the increased activities of the older Development Fund grew up piecemeal, with little co-ordination and in the absence of any carefully thought-out or balanced scheme. To such an extent has this proved the case that many scientific workers themselves have found it diff. cult to ascertain the proper body to consult in connexion with a piece of work they may have had in hand ; whilst to the layman the multiplicity of bodies making grants and the trouble of discovering to which to apply has furnished proof, if proof were wanting, of the inadequacy of the methods in force. Attention was directed to this state of affairs in these columns so long ago as July 26, 1930. 
Owing to the lack of unified control over the allocation of grants by the various bodies in existence, it became apparent that Parliament had very little voice in the matter. It was being asked by different bodies to make provision for carrying out objects which were seemingly substantially the same, though this was not evident in the Estimates presented to the House of Commons; nor was it easy to appreciate the position after a close study. For these reasons the matter has been investigated by the Estimates Committee of the House, of which Sir Vivian Henderson is chairman. The first report of this Committee has now been presented to Parliament, and was referred to in Nature of April 16, p. 572. The Committee has confined itself to an examination of the estimates of the above-mentioned funds and services. The report is timely and will prove illuminating to the public, though it may present few surprises to those conversant with the position.

It has been difficult for research workers and others to discover in how far the various bodies receiving grants from Government have been cognisant with the work being undertaken by their confrères, but the Committee does not suggest that the bodies and departments allotting grants are in ignorance of the position. Nevertheless, the Committee has discovered that grants are being made by the Empire Marketing Board for many purposes which are also assisted by the Department of Scientific and Industrial Research, the Ministry of Agriculture, the Development Fund, and the Forestry Commission. Many institutions are receiving grants from the State through one or more, or even up to five or more, different sources. It is also apparent that grants are being made from the Colonial Development Fund for ordinary purposes of government in Colonies which are at the same time in receipt of a grant-in-aid from the Colonial Office. It has thus become apparent ( 1 ) that Parliament is not in a position to ascertain with ease the total assistance it is granting to one institution; (2) that the multiplicity of grants obtained by one institution from several different bodies results in a greater total being given than would be the case if the total sum were voted by Parliament itself in a single grant.

The Committee directs attention to the longestablished canon of sound finance by which all government aid for any one purpose or any one body should be provided in a single grant. It is recognised that this ideal may often be unattainable; but the Committee considers that it is

No. 3264, VoL. 129] essential, before this principle is departed from in any one case, to make sure that there are adequate grounds for so doing.

The Committee is therefore of opinion that, even if bodies and departments have extant elaborate arrangements for maintaining the essential coordination, the necessity for such arrangements appears to challenge the efficiency of the present system and to constitute a strong case for reviewing it. It therefore recommends that the Estimates should be so framed in future that the total State grant allocated to any institution should be readily ascertainable.

The authors of the report have expressed no opinion on the policy of assisting the various objects for which grants are made, but they are of opinion that they may properly review the very complicated machinery by which that policy is being carried into effect. Various political and Empire questions, including the adoption of a general tariff and the approaching Ottawa Conference, which need not be entered into here, have come to the front to make the moment opportune for this review. The tariff and Empire preferences, for example, alter the basis upon which the Empire Marketing Board was formed in 1926; and the working of the Colonial Development Fund can now be reviewed in the light of experience which has been gained.

The Committee directs attention to the threefold organisation for medical, agricultural, and industrial research, under the Lord President of the Council, now taking shape in Great Britain; its suggestion that these bodies should gradually become the controlling departments in their respective spheres will be welcomed.

In the event of effect being given to the Committee's suggestions, the new Advisory Council for Agricultural Research could take over portions of the work of the Development Fund, whilst certain of the work of the Empire Marketing Board might be absorbed by the relevant trade intelligence service. The grants from the Colonial Development Fund should be restricted, as was originally intended, to works of a capital nature, and grants such as have been recently sanctioned for ordinary government administrative purposes should be discontinued.

As regards the inter-relation and co-ordination of grants by the different Empire administrations, the Committee's report should enable this important side of the problem to be discussed with an added insight at the Ottawa Conference to be held in July. 